Lepr Rev (1989) 60, 267-273

\title{
Increased incidence in leprosy of hypersensitivity reactions to dapsone after introduction of multidrug therapy
}

\author{
J H RICHARDUS \& T C SMITH \\ McKean Rehabilitation Centre, Chiang Mai 50000, Thailand
}

\author{
Accepted for publication 25 August 1989
}

\begin{abstract}
Summary In order to address the question whether hypersensitivity reactions to dapsone are becoming more frequent, the clinical data of 7300 leprosy patients treated between 1949 and September 1988 at the McKean Rehabilitation Centre in Thailand were reviewed.

Information from the period 1949 to 1969 was too incomplete to allow conclusions. The incidence of hypersensitivity reactions to dapsone between 1970 and 1982 was $0 \cdot 3 \%$. From 1982 (with the introduction of multidrug therapy) to September 1988, the incidence was $3.6 \%$; a tenfold increase compared with the previous period. Of the 19 cases seen since 1982, 12 were diagnosed as Dapsone syndrome. Of a total of 13 patients seen since 1980 with Dapsone syndrome, 3 ended fatally, indicating the severity of the complication.

The question is raised whether an unexplained drug interaction with rifampicin is responsible for the increase of hypersensitivity reactions to dapsone in patients treated for leprosy.
\end{abstract}

\section{Introduction}

Diaminodiphenylsulphone (dapsone or DDS) has been used for over 40 years in the treatment of a variety of conditions including leprosy, dermatitis herpetiformis and a number of less common dermatological diseases. Although dapsone is considered a very safe drug, side-effects are many and varied. Apart from a number of adverse reactions and toxic effects associated with dapsone, ${ }^{1-3} \mathrm{a}$ distinct hypersensitivity reaction to dapsone has been described. ${ }^{4-7}$

This reaction or 'Dapsone syndrome', was originally described as characterized by the sudden onset of a papular or exfoliative rash, accompanied by fever, malaise and weakness and followed by enlargement and tenderness of the liver, jaundice, lymphadenopathy and mononucleosis after 5 or 6 weeks of dapsone therapy. Not all symptoms were necessarily present. ${ }^{5}$

Cutaneous manifestations in hypersensitivity reactions to dapsone show wide variations, including erythroderma, papuloerythematous eruptions, erythema multiforme, toxic epidermal necrolysis and the Stevens-Johnson syndrome. ${ }^{8}$

Hypersensitivity reactions were reported in a very limited number of leprosy patients up to the late 1970s. Since then there has been an increasing number of case reports from different continents. These reports have recently been reviewed. ${ }^{9}$ The question was raised whether hypersensitivity reactions to dapsone are becoming more frequent. In an attempt to answer this question on a more 
regional level, we reviewed the histories of leprosy patients treated with dapsone at the McKean Rehabilitation Centre in Chiang Mai, northern Thailand during the past 40 years.

\section{Methods}

The McKean Rehabilitation Centre in Chiang Mai, northern Thailand, has been a (church-related) treatment institute for leprosy patients since 1908. It serves patients from the whole of the northern Thailand area (population approximately 10 million). Sulphones were introduced at the Centre in 1949. In the late 1950s, 1960s and 1970s, dapsone monotherapy was the mainstay of therapy, alternating because of intolerance (which usually meant erythema nodosum leprosum (ENL)) with antibacterial drugs such as thiacetazone, thiambutosine, streptomycin, isoniazid and clofazimine. Multidrug therapy (MDT) according to the recommendations of the WHO, ${ }^{10}$ was introduced by the end of 1982. A minor variation on the WHO regimen was made in that rifampicin $600 \mathrm{mg}$ was given on 2 consecutive days per month instead of once monthly.

The available clinical data of patients treated with dapsone between 1949 and September 1988 were reviewed for the occurrence of adverse reactions attributed to dapsone. Case histories had to meet a number of criteria bef ore the diagnosis of a true dapsone hypersensitivity reaction was made:

1, the symptoms appeared within 8 weeks after commencement of dapsone and disappeared after discontinuation of the drug; 2 , the symptoms could not be ascribed to any other drug given simultaneously with dapsone; if any other drugs were taken at the same time, these could be resumed after stopping dapsone without inducing similar reactions; 3, symptoms were not attributable to lepra reactions; and 4, no other diseases liable to cause similar symptoms were diagnosed.

Final proof by trial administration of dapsone after the original reaction had subsided (as was performed in a number of cases), was not considered necessary as an absolute criterion due to the risks involved in some patients.

A hypersensitivity reaction was classified as 'Dapsone syndrome' when, apart from the above stated criteria: 1, symptoms started between 2 and 8 weeks af ter commencement of dapsone, and 2, at least two of the following signs or symptoms were present: fever, skin eruption, lymphadenopathy and liver pathology (in the form of hepatomegaly, jaundice and/or abnormal liver function tests).

\section{Results}

In reviewing the clinical data accumulated at the Centre, three distinct periods could be distinguished: 1, the period from the introduction of dapsone in 1949 to $1969 ; 2,1970$ to November 1982; and 3, November 1982 to September 1988. The first period was characterized by incomplete data. Since 1970 records have been kept more consistently, the caseload decreased gradually and more time was spent on the individual patients. At the end of 1982 the new era of MDT was commenced. A total of 7300 charts were examined. Table 1 reviews the treatment regimen policies during these periods.

Hypersensitivity reactions attributed to dapsone could be divided into four categories (Table 2). In a number of cases sufficient information was not available. These are listed separately. In 13 cases the reaction was positively proven to be caused by dapsone by giving a trial administration of the drug after the original symptoms had subsided.

Table 3 gives general data of the 13 patients diagnosed as having a 'Dapsone syndrome' and Table 4 shows the main clinical signs and symptoms associated with the reaction. Finally, in Table 5 , attack rates of hypersensitivity reactions in the period 1982 to 1988 are analysed according to age group and sex. There is no significant age or sex association. 
Table 1. Analysis of treatment regimen policies at the McKean Rehabilitation Centre, 1949-88.

\begin{tabular}{|c|c|c|c|}
\hline Period & Years & Dominant therapy policy & Alternatives \\
\hline \multirow[t]{3}{*}{ I } & $1949-50$ & Chaulmoogra oil & Diasone drug trials \\
\hline & $1951-56$ & $\begin{array}{l}\text { Dapsone: low dose start, } \\
\text { reaching } 300 \mathrm{mg} 2 / \text { week } \\
\text { after } 6 \text { months }\end{array}$ & $\begin{array}{l}\text { Sulphetrone } \\
\text { Avlosulfon injections }\end{array}$ \\
\hline & $1957-69$ & $\begin{array}{l}\text { Dapsone, low dose, irregular, } \\
\text { intermittent. Policy of } \\
\text { stopping whenever ENL } \\
\text { occurred }\end{array}$ & $\begin{array}{l}\text { Rimifon (INAH) } \\
\text { Thiacetazone (TB1) } \\
\text { Thiambutosine (CIBA 1906) } \\
\text { Streptomycin }\end{array}$ \\
\hline \multirow[t]{6}{*}{ II } & $1970-74$ & $\begin{array}{l}\text { Dapsone, starting } 10 \mathrm{mg} \\
\text { 2/week, reaching } 100 \mathrm{mg} \\
\text { 3/week after } 8 \text { months }\end{array}$ & $\begin{array}{l}\text { Thiambutosine } \\
\text { Clofazimine (B663) }\end{array}$ \\
\hline & $1975-76$ & $\begin{array}{l}\text { Dapsone, starting } 50 \mathrm{mg} \\
\text { 2/week, reaching } 100 \mathrm{mg} \\
\text { 3/week after } 4 \text { months }\end{array}$ & $\begin{array}{l}\text { Clofazimine } \\
\text { Thiacetazone }\end{array}$ \\
\hline & $1977-80$ & $\begin{array}{l}\text { Dapsone, starting } 50 \mathrm{mg} \\
\text { daily in combination } \\
\text { with clofazimine } 100 \mathrm{mg} \\
\text { 3/week (MB) }\end{array}$ & $\begin{array}{l}\text { Rifampicin (f or relapsed } \\
\text { cases only) } \\
\text { Thiacetazone }\end{array}$ \\
\hline & & Dapsone 50 mg daily (PB) & \\
\hline & $1981-82$ & $\begin{array}{l}\text { Dapsone } 100 \mathrm{mg} \text { daily } \\
\text { with clofazimine } 100 \mathrm{mg} \\
\text { 3/week (MB) }\end{array}$ & $\begin{array}{l}\text { Rifampicin (f or relapsed } \\
\text { cases only) }\end{array}$ \\
\hline & & Dapsone 100 mg daily (PB) & \\
\hline \multirow[t]{2}{*}{ III } & $1982-88$ & $\begin{array}{l}\text { Dapsone } 100 \mathrm{mg} \text { daily } \\
\text { plus clofazimine } 100 \mathrm{mg} \\
\text { 3/week plus rifampicin } \\
1200 \mathrm{mg} \text { per month (MB) }\end{array}$ & $\begin{array}{l}\text { Ethionamide (if intolerant } \\
\text { to MDT) }\end{array}$ \\
\hline & & $\begin{array}{l}\text { Dapsone } 100 \mathrm{mg} \text { daily } \\
\text { plus rifampicin } 1200 \mathrm{mg} \\
\text { per month (PB) }\end{array}$ & \\
\hline
\end{tabular}

PB, paucibacillary; MB, multibacillary.

A summary of five significant case histories follows:

Case No. 1 concerns a 22-year-old Thai male, was admitted on 16/5/1980 for elective surgical correction of a dropped foot, which had existed for 6 years. The diagnosis of tuberculoid leprosy (TT) was made and he was started on dapsone monotherapy (100 mg daily). Surgery was perf ormed on 4/6/1980. Recovery was uneventful and there were no postoperative complications or infections. On 16/6/1980 an erythematous rash developed on both arms, which spread over the whole body during the following few days. On 21/6/1980 it was described as a general maculopapular rash with an itchy and burning sensation and diagnosed as Stevens-Johnson syndrome. Fever existed. Dapsone was now stopped and antihistamines were given, followed by corticosteroids. The skin lesions progressed into a vesiculopustular rash with purpuric background. On 25/6/1980 a facial oedema and throat discomfort developed. The same afternoon the patient died suddenly. Blood examination showed thrombocytopenia and agranulocytosis.

Case No. 6 is a 28-year-old male of Hilltribe origin. He was admitted on 8/11/1984 with 
Table 2. Number and nature of hypersensitivity reactions to dapsone at the McKean Rehabilitation Centre, 1949-88

\begin{tabular}{|c|c|c|c|}
\hline \multirow[b]{2}{*}{ Category of reaction } & \multicolumn{3}{|c|}{ Number per time period } \\
\hline & $1949-69$ & $1970-82$ & $1982-88$ \\
\hline $\begin{array}{l}\text { Reported dapsone 'allergy', } \\
\text { but not enough data to } \\
\text { substantiate claim. }\end{array}$ & 9 & 6 & 0 \\
\hline $\begin{array}{l}\text { Early (within } 2 \text { weeks) } \\
\text { reaction after start of } \\
\text { dapsone, characterized } \\
\text { by a skin eruption only. }\end{array}$ & $7(6)^{*}$ & $6(2)$ & $3(2)$ \\
\hline $\begin{array}{l}\text { Delayed ( } 2-8 \text { weeks) } \\
\text { reaction after start of } \\
\text { dapsone, characterized } \\
\text { by a skin eruption only. }\end{array}$ & 0 & 1 & $4(1)$ \\
\hline Hepatitis only & $1(1)$ & 0 & 0 \\
\hline Dapsone syndrome & 0 & 1 & $12(1)$ \\
\hline Total & 17 & 14 & 19 \\
\hline
\end{tabular}

* Number of cases (in brackets) in which the reaction was proven by trial administration of dapsone.

lepromatous leprosy (LL). The skin smear was 3.7+. He was started on MDT-MB. Spiking fevers were first noticed on 14/12/1984. There was no ENL and no other cause of the fever was found. On $19 / 12 / 1984$ scleral icterus was seen, followed by generalized adenopathy. The liver was enlarged. On 20/12/1984 a non-itchy rash appeared on the limbs (peripheral distribution) which became more generalized in the following 2 days. Differential diagnosis included typhus, typhoid, malaria, glandular fever, dengue, hepatitis and ENL. Liver function tests showed slightly elevated SGOT, SGPT, alkaline phosphatase and bilirubin values. Malaria smears were negative. Thalidomide,

Table 3. General data of 13 patients with Dapsone syndrome at the McKean Rehabilitation Centre

\begin{tabular}{|c|c|c|c|c|c|c|c|}
\hline \multirow[b]{2}{*}{ No. } & \multirow[b]{2}{*}{ Sex } & \multirow{2}{*}{$\begin{array}{l}\text { Age in } \\
\text { years }\end{array}$} & \multirow{2}{*}{$\begin{array}{l}\text { Leprosy } \\
\text { class }\end{array}$} & \multirow{2}{*}{$\begin{array}{l}\text { Date of } \\
\text { start }\end{array}$} & \multirow{2}{*}{$\begin{array}{l}\text { Dose of } \\
\text { dapsone }\end{array}$} & \multicolumn{2}{|c|}{$\begin{array}{l}\text { Other antileprosy } \\
\text { medication }\end{array}$} \\
\hline & & & & & & MDT-MB & MDT-PB \\
\hline 1 & $\mathbf{M}$ & 22 & TT & $05 / 1980$ & $100 \mathrm{mg}$ & - & - \\
\hline 2 & M & 24 & TT & $02 / 1983$ & $100 \mathrm{mg}$ & - & + \\
\hline 3 & $\mathrm{~F}$ & 18 & $\mathrm{BL}$ & $02 / 1983$ & $100 \mathrm{mg}$ & + & - \\
\hline 4 & M & 22 & BT & $11 / 1983$ & $100 \mathrm{mg}$ & - & + \\
\hline 5 & $\mathbf{M}$ & 18 & BT & $01 / 1984$ & $100 \mathrm{mg}$ & - & + \\
\hline 6 & $\mathrm{M}$ & 28 & LL & $11 / 1984$ & $100 \mathrm{mg}$ & + & - \\
\hline 7 & $\mathbf{M}$ & 35 & LL & $02 / 1986$ & $100 \mathrm{mg}$ & + & - \\
\hline 8 & $\mathrm{~F}$ & 46 & BL & $01 / 1987$ & $100 \mathrm{mg}$ & + & - \\
\hline 9 & $\mathbf{M}$ & 76 & BL & $04 / 1987$ & $100 \mathrm{mg}$ & + & - \\
\hline 10 & M & 31 & LL & $05 / 1987$ & $100 \mathrm{mg}$ & + & - \\
\hline 11 & $\mathbf{M}$ & 10 & TT & $09 / 1987$ & $50 \mathrm{mg}$ & - & + \\
\hline 12 & $\mathrm{M}$ & 27 & $\mathrm{BL}$ & $10 / 1987$ & $100 \mathrm{mg}$ & + & - \\
\hline 13 & $\mathrm{~F}$ & 22 & $\mathrm{BL}$ & $03 / 1988$ & $100 \mathrm{mg}$ & + & - \\
\hline
\end{tabular}


Table 4. Medical data of 13 patients with Dapsone syndrome at the McKean Rehabilitation Centre

\begin{tabular}{|c|c|c|c|c|c|c|c|c|}
\hline \multirow[b]{2}{*}{ No. } & \multirow{2}{*}{$\begin{array}{c}\text { Time of } \\
\text { onset } \\
\text { (days) }\end{array}$} & \multicolumn{3}{|c|}{ Skin eruptions } & \multirow[b]{2}{*}{ Fever } & \multirow[b]{2}{*}{ Lymphadenopathy } & \multirow{2}{*}{$\begin{array}{c}\text { Hepatic } \\
\text { involvement }\end{array}$} & \multirow[b]{2}{*}{ Outcome } \\
\hline & & itch & erythema & exfoliation & & & & \\
\hline 1 & 31 & + & + & + & + & - & - & died \\
\hline 2 & 35 & + & + & - & + & - & - & recovered \\
\hline 3 & 36 & + & + & + & + & - & - & recovered \\
\hline 4 & 46 & + & + & + & + & - & + & recovered \\
\hline 5 & 28 & - & + & + & + & + & + & recovered \\
\hline 6 & 36 & - & + & - & + & + & + & died \\
\hline 7 & 25 & - & + & + & + & + & + & recovered \\
\hline 8 & 18 & + & + & + & + & - & - & recovered \\
\hline 9 & 28 & - & + & - & + & + & + & died \\
\hline 10 & 28 & - & + & + & + & $?$ & + & recovered \\
\hline 11 & 39 & - & + & + & + & $?$ & + & recovered \\
\hline 12 & 42 & + & + & + & + & + & + & recovered \\
\hline 13 & 14 & + & + & + & + & + & - & recovered \\
\hline
\end{tabular}

chloramphenicol and penicillin were started but had no effect. The condition of the patient deteriorated and on 25/12/1984 he was transferred to the University Hospital of Chiang Mai under the diagnosis of possible Dapsone syndrome. The patient died on 2/1/1985 due to hepatic failure and toxic shock.

Case No. 9 is a 76-year-old Chinese man who was admitted on 28/4/1987 after borderline lepromatous leprosy (BL) was diagnosed (skin smear 3.7+). He was started on MDT-MB. Low grade fevers developed n 20/5/1987, but no signs of ENL or other causes for the fever were found. Penicillin was started orally on 26/5/1987, but this had no effect and was stopped on 28/5/1987. Before other examinations could be initiated, his condition deteriorated rapidly. He developed sores in the mouth, a diffuse erythematous rash appeared and he became jaundiced. On 31/5/1987 dapsone was stopped and he was transferred to the University Hospital of Chiang Mai where he died on 7/6/1987 because of hepatic failure.

Table 5. Incidence of hypersensitivity reactions to dapsone in previously untreated leprosy patients started on MDT in the period 1982 to 1988 at the McKean Rehabilitation Centre, divided into age group and sex

\begin{tabular}{|c|c|c|c|c|c|c|}
\hline \multirow[b]{2}{*}{$\begin{array}{l}\text { Age group } \\
\text { (years) }\end{array}$} & \multicolumn{3}{|c|}{ Male } & \multicolumn{3}{|c|}{ Female } \\
\hline & $n$ & $\begin{array}{l}\text { Dapsone } \\
\text { reaction }\end{array}$ & $\%$ & $n$ & $\begin{array}{l}\text { Dapsone } \\
\text { reaction }\end{array}$ & $\%$ \\
\hline $0-4$ & 1 & 0 & 0 & 1 & 0 & 0 \\
\hline $5-9$ & 16 & 0 & 0 & 3 & 0 & 0 \\
\hline $10-14$ & 21 & 1 & $4 \cdot 8$ & 8 & 0 & 0 \\
\hline $15-19$ & 29 & 1 & $3 \cdot 4$ & 10 & 1 & 10 \\
\hline $20-24$ & 39 & 2 & $5 \cdot 1$ & 13 & 2 & $15 \cdot 4$ \\
\hline $25-34$ & 85 & 3 & $3 \cdot 5$ & 28 & 0 & 0 \\
\hline $35-44$ & 56 & 1 & $1 \cdot 8$ & 22 & 1 & $4 \cdot 5$ \\
\hline $45-54$ & 68 & 2 & $2 \cdot 9$ & 23 & 1 & $4 \cdot 3$ \\
\hline $55-64$ & 46 & 2 & $4 \cdot 3$ & 14 & 1 & $7 \cdot 1$ \\
\hline$>65$ & 27 & 1 & $3 \cdot 7$ & 14 & 0 & 0 \\
\hline Total & 388 & 13 & $3 \cdot 4$ & 136 & 6 & $4 \cdot 4$ \\
\hline
\end{tabular}


Case No. 10 concerns a 31-year-old male of Hilltribe orıgn. He was diagnosed with lepromatous leprosy (LL; skin smear 2.8+). MDT-MB was started and he returned home on the same day (18/5/1987). On 18/6/1987 he presented himself at the University Hospital of Chiang Mai with high grade fever and a generalized maculopapular rash. Dapsone syndrome was suspected, dapsone and rifampicin were discontinued, a course of prednisolone was started and he was referred back to the Centre. On 3/7/1987 jaundice was noticed and liver function tests showed slight elevations of SGOT, SGPT and alkaline phosphatase. Serological tests for Hepatitis A and B were negative. The patient recovered well and continued treatment on clofazimine. Rifampicin has not yet been resumed.

On 21/9/1987 Patient No. 10 brought in his 10-year-old son (Case No. 11). The boy had hypopigmentated patches on his face; the $(R)$ great auricular nerve and $(R)$ ulnar nerve were enlarged. Skin smears showed no acid-fast bacteria. He was diagnosed as having tuberculoid leprosy (TT) and started on MDT-PB (child dose: half strength). On 2/11/1987 he returned with fever and abdominal pain and swelling, accompanied by nausea and vomiting. There was a marked erythematous papular rash with exfoliation. Symptoms had started 4 days previously. The liver was enlarged and ascitis existed. All therapy was stopped and the patient was sent to the University Hospital and treated for Dapsone syndrome with prednisolone. This had to be continued for 2 months, but eventually there was a good recovery and the boy continued with rifampicin and clofazimine afterwards without further problems.

\section{Discussion}

Dapsone syndrome is basically a clinical diagnosis and often made and treated under 'field conditions'. Thorough analysis of haematological, immunological and biochemical features of hypersensitivity reactions to dapsone was beyond the scope of this retrospective study.

The information gathered between 1949 and 1969 is too incomplete for valid analysis. In the period between 1970 and 1982, 2350 new, previously untreated patients were started on dapsone. Hypersensitivity was observed in 8 patients, of which 6 had an early onset with skin eruptions only (incidence $0 \cdot 3 \%$ ). If we include the other 6 cases of dubious diagnosis, the incidence is $0 \cdot 6 \%$. After implementation of MDT in 1982, 19 cases of dapsone hypersensitivity have been diagnosed: 12 were labelled as Dapsone syndrome, 3 as early onset and 4 as delayed onset with skin eruptions only. In this period, 524new, previously untreated, patients were started on MDT. The incidence of dapsone hypersensitivity reaction is thus $3 \cdot 6 \%$, a tenfold rise compared with the 1970-1982 period.

A number of important factors can be mentioned as possibly contributing to the observed rise: 1 Increased awareness. Although experience with side -effects from dapsone have always existed in the Centre, it can be argued that awareness amongst medical staff was enhanced by the sudden tragic death of a young patient in 1980 (No. 1, Tables 3 and 4). The increase in the number of reports in literature since 1980 may also have contributed to greater awareness. Besides this, the implementation of MDT has intensified monitoring of patients starting treatment.

2 Low dose regimens of dapsone before 1976. Table 1 shows that it was common practice before 1976 to start treatment with low amounts of dapsone and gradually increase the dosage. One wonders if this policy desensitized patients to the drug. Successful desensitization to dapsone in a comparable way was described by Browne in $1963 .{ }^{11}$

3 Quality of dapsone. Changes in manufacturing since 1949 and even storage time might explain chemical changes leading to hypersensitivity. This needs to be clarified.

4 Combination with other antileprosy drugs. The combination of high dose dapsone with rifampicin seems to be the common factor when comparing the various drug regimens to explain the increased incidence of hypersensitivity reactions. Dapsone 50 or $100 \mathrm{mg}$ daily combined with clofazimine 100 mg three times per week was used between 1976 and 1982 without a noticeable increase of reactions. 
Since the introduction of MDT, hypersensitivity reactions have beenseen in both patients on MDTMB (with clofazimine) and MDT-PB (without clofazimine).

The question is whether rifampicin sensitizes certain susceptible people to dapsone, especially in the combination of dosages used in MDT.

Our study shows an apparent increase in hypersensitivity reactions to dapsone after the introduction of MDT. We believe, certainly within the context of the Centre, that this observation reflects a true rise in incidence. The possibility of rifampicin as a contributing factor to the increase of dapsone reactions is suggestive and should be seriously considered and investigated. In our experience, no patients who were previously on dapsone monotherapy, developed a hypersensitivity reaction after beginning MDT. It could be advised that MDT treatment schedules are adapted in such a way that dapsone is given at least 8 weeks before starting rifampicin.

\section{References}

${ }^{1}$ DeGowin RL. A review of therapeutic and hemolytic effects of dapsone. Arch Intern Med, 1967; 120: 242-8.

2 Graham WR. Adverse effects of dapsone. Int J Derm, 1975; 14: 494-500.

${ }^{3}$ Shelley WB, Goldwein MI. High dose dapsone toxicity. Br J Derm, 1976; 95: 79-82.

${ }^{4}$ Jelliffe DB. Toxic hepatitis caused by diamino-diphenylsulphone. Lancet, 1951; i: 1343-4.

5 Allday EJ, Barnes J. Toxic effects of diamino-diphenylsulphone in treatment of leprosy. Lancet, 1951; ii: 2056.

${ }^{6}$ Tomecki KJ, Catalano CJ. Dapsone hypersensitivity. Arch Dermatol, 1981; 117: 38-9.

7 Kromann NP, Vilhelmsen R, Stahl D. The Dapsone syndrome. Arch Dermatol, 1982; 118: 531-2.

${ }^{8}$ Browne SG, Ridge E. Toxic epidermal necrolysis. Br Med J, 1961; 1: 550-3.

${ }^{9}$ Smith WCS. Are hypersensitivity reactions to dapsone becoming more frequent? Lepr Rev, 1988; 59: 53-8.

${ }^{10}$ WHO Study Group. Chemotherapy of leprosy for control programmes. WHO Technical Report Series No. 675. WHO: Geneva 1982.

1 Browne SG. Desensitization for dapsone dermatitis. Br Med J, 1963; 2: 664-6. 